\title{
Suplementasi Campuran Tepung Kunyit dan Sambiloto dalam Ransum terhadap Performan Ayam Petelur
}

\section{Supplementation of Turmeric and Andrographis paniculata Powder in Ration on Performance of Laying Hen}

\author{
F. X. Suwarta ${ }^{1 *}$, C. L. Suryani ${ }^{2}$ dan L. Amien ${ }^{1}$ \\ ${ }^{1}$ Program Studi Peternakan, Fakultas Agroindustri, Universitas Mercu Buana, Yogyakarta \\ ${ }^{2}$ Program Studi Teknologi Pangan, Fakultas Agroindustri, Universitas Mercu Buana, Yogyakarta \\ Jl. Wates KM 10 Yogyakarta - Indonesia \\ *Corresponding E-mail: fxsuwarta@gmail.com
}

(Diterima: 22 November 2020; Disetujui: 18 Maret 2021)

\begin{abstract}
ABSTRAK
Salah satu metode untuk memperbaiki produksi unggas yang saat sekarang berkembang di Indonesia adalah dengan mensuplementasikan bahan herbal. Tujuan penelitian ini untuk mengetahui pengaruh suplementasi campuran tepung sambiloto dan kunyit terhadap performan ayam petelur Isa Brown umur 17-30 minggu. Rancangan penelitian menggunakan rancangan acak lengkap, terdiri dari lima perlakuan, dan setiap perlakuan diulang 3 kali. Masing-masing ulangan menggunakan 10 ekor ayam petelur strain Isa Brown. Kelima perlakuan terdiri dari P0: (0 g kunyit $+0 \mathrm{~g}$ sambiloto)/kg pakan; P1 : ( 5 g kunyit +5 g sambiloto)/kg pakan; P2: (10 g kunyit+ $10 \mathrm{~g}$ sambiloto)/kg pakan, P3: ( 15 kunyit $+15 \mathrm{~g}$ sambiloto) $/ \mathrm{kg}$ pakan dan P4: (20 g kunyit $+20 \mathrm{~g}$ sambiloto). Variabel yang diamati meliputi konsumsi pakan, produksi telur (HDA), umur dewasa kelamin, konversi pakan, berat telur, yolk dan berat kerabang. Dari penelitian menunjukkan suplementasi campuran sambiloto dan kunyit masing-masing pada level $10 \mathrm{~g} / \mathrm{kg}$ dalam ransum dapat memperbaki produksi telur dan konversi pakan, namun tidak mempengaruhi konsumsi pakan, umur dewasa kelamin, berat telur, berat yolk dan berat kerabang. Suplementasi campuran tepung kunyit dan sambiloto pada level diatas $10 \mathrm{~g} / \mathrm{kg}$ akan menghasilkan kinerja lebih buruk untuk semua variabel. Disimpulkan suplementasi campuran tepung sambiloto dan kunyit $(10 \mathrm{~g}+10 \mathrm{~g}) / \mathrm{kg}$ dapat memperbaiki produksi telur dan konversi pakan pada ayam petelur.
\end{abstract}

Kata kunci: ayam petelur, kinerja, kunyit, sambiloto

\section{ABSTRACT}

The utilization of herbal ingredients to improve poultry production in Indonesia is more developed. This study aimed to discover the effect of mixed supplementation of turmeric powder and Andrographis paniculata on the performance of Isa Brown laying hen (17 - 30 weeks old). This study consisted of five treatments with three replications (10 laying hen per replicate) and used Complete Random Design. This experiment conducted with five groups of treatments: P0 (control); P1 (5 g turmeric $+5 \mathrm{~g}$ A. paniculata)/ $\mathrm{kg}$ of feed; $P 2$ (10 g turmeric $+10 \mathrm{~g}$ Andrographis paniculata) $/ \mathrm{kg}$ of feed; P3 (15 g turmeric $+15 \mathrm{~g} \mathrm{~A}$. paniculata)/kg of feed and P5 (20 g turmeric $+20 \mathrm{~g}$ A. paniculata) $/ \mathrm{kg}$ of feed. Feed intake, age of sexual maturity, egg production (HDA), feed conversion, egg weight, yolk, and shell weight were observed. The results of statistical analysis show that mixed supplementation of turmeric and A. paniculata at level $10 \mathrm{~g} /$ $\mathrm{kg}$ offeed was improved egg production (HDA) and feed conversion but didn't have an effect on feed intake, age of sexual maturity, egg weight, yolk weight, and shell weight. Mixed supplementation of turmeric and A. paniculata powder at levels above $10 \mathrm{~g} / \mathrm{kg}$ showed more unsatisfactory performance for all variables. This Study reveals that mixed supplementation of turmeric and A.paniculata $(5 \mathrm{~g}+5 \mathrm{~g}) / \mathrm{kg}$ of feed was improved the production of egg and feed conversion of laying hens.

Keywords: laying hen, turmeric, Andrographis paniculata, performance 


\section{PENDAHULUAN}

Di Indonesia ayam petelur adalah unggas yang menyumbang telur terbesar secara nasional. Di Indonesia jumlah ayam ras petelur pada tahun 2019 mencapai 263.918 ribu ekor dan menghasilkan produksi telur 4.753.000 ton (DJPKH, 2019). Antibiotik banyak digunakan untuk menjaga kesehatan dan meningkatkan produktivitas pada ayam petelur. Mengingat penggunaan antibiotik mengakibatkan adanya resistensi pada beberapa bakteri dan menyisakan residu pada produk ternak maka pada saat sekarang penggunaan antibiotik pada unggas mulai dibatasi. Mengingat efek negatif tersebut dikembangkan produk antibiotik alami bersumber pada herbal (fitobiotik) untuk memperbaiki produksi unggas. Perbaikan performan unggas dengan menggunakan fito biotik dinilai lebih aman karena menghasilkan produk bebas residu, toksisitasnya rendah, berharga murah dan dapat memperbaiki produksi ternak. Keuntungan yang diperoleh dari penggunaan bahan herbal pada ternak yaitu kandungan antioksidannya dan mampu memperbaiki kekebalan, pertumbuhan, efisiensi pakan, menekan pertumbuhan bakteri yang merugikan, menurunkan kadar kholesterol, dan trigliserida (Houshmand et al., 2012); (Jouybari et al., 2009). Suplementasi bahan herbal yang digunakan secara campuran pada ransum unggas akan memberikan manfaat yang lebih baik, dibandingkan jika digunakan secara tunggal. Bahan-bahan herbal seperti ekstrak artemisia, thyme, oregano, dan rosemary dapat memperbaiki pertumbuhan dan produksi unggas jika disuplementasikan dalam ransum. Bahan herbal yang banyak ditemukan dan tumbuh di Indonesia adalah sambiloto (Andrographis paniculata) dan kunyit (Curcuma longa).

Sambiloto adalah salah satu tanaman herbal yang memiliki kandungan fitobiotik. Sambiloto mengandung zat aktif yang dikenal dengan andrografolida, dan memberikan rasa pahit, serta mempunyai aktivitas sebagai antitoksik, mencegah kanker, anti alergi, anti radang dan anti bakteri (Joseph and Solomon, 2014). Sambiloto mengandung beberapa senyawa aktif yang dikenal dengan xanthone, neoandrogtapholide, dan diterpene phytoconstituents yang berperan sebagai antidiare. Pada tanaman sambiloto terdapat senyawa 14-deoxyandrographolide dan 14-deoxy-11,12 dehidroandrographolide yang mempunyai aktivitas sebagai antioksidan yang cukup efektif. Penelitian Tipakorn (2002), menyatakan ayam broiler yang diberi $0,45 \%$ bubuk sambiloto dalam ransumnya akan menekan mortalitas dan koksidiosis.

Kunyit diperoleh dari rimpang tanaman kunyit (Curcuma longa). Curcumin, demethoxycurcumin, methoxycurcumin, dan tetrahydrocurcuminoid merupakan senyawa aktif yang terkandung dalam kunyit (Kiuch et al., 1993). Curcumin sangat populer dikenal sebagai pigmen kuning dengan peranan cukup luas diantaranya sebagai pencegah oksidasi, antiradang, dan pembunuh cacing (Kiuch et al., 1993; Ammon et al., 1993; Osawa et al., 1995). Di Indonesia, untuk membuat jamu tradisional, memberikan pewarna alami, memperbaiki rasa dan mengawetkan makanan, banyak digunakan kunyit.

Dinyatakan oleh Abdullah et al. (2010), senyawa aktif dalam kunyit yang berupa fenolic mempunyai aktivitas sebagai carcinogenesis karena bersifat antimutagenic dan antioksidative. Tepung kunyit yang disuplementasikan dalam ransum unggas dapat memperbaiki kecernaan, karena mampu merangsang sekresi enzim pencernaan dan enzim lipase dari pankreas (Platel and Srinivasan, 2000). Penggunaan tepung kunyit pada level 0,2 g/kg akan memperbaiki berat dan panjang usus kecil sehingga akan memperbaiki efisiensi penyerapan nutrien (Rajput et al., 2013). Dalam saluran cerna, curcumin dapat menghambat penyerapan kholesterol (Arafa, 2005). Kandungan kholesterol dan trigliserida darah puyuh akan menurun sebagai akibat suplementasi tepung kunyit, diikuti dengan penurunan kholesterol, LDL, dan peningkatan HDL telur puyuh (Saraswati et al., 2013; Saraswati et 
al., 2014; Saraswati dan Tana, 2016). Kadar phyotoestrogen dalam tepung kunyit sebesar $7,97 \mathrm{mg} / \mathrm{g}$ dan bersifat estrogenic, sehingga dapat meningkatkan pertumbuhan folikel ovarium (Saraswati et al., 2014). Dinyatakan oleh Gumus et al. (2018) ransum ayam petelur Isa Brown yang disuplementasi dengan campuran tepung kunyit dan sambiloto akan memperbaiki produksi dan berat telur serta memperbaiki efisiensi pakan.

Dari uraian tersebut dilakukan penelitian untuk mengkaji pengaruh suplementasi campuran tepung sambiloto dan kunyit dalam ransum terhadap kinerja ayam petelur Isa Brown pada umur 17-30 minggu.

\section{METODE}

\section{Tempat Penelitian}

Penelitian dilakukan di kandang ayam petelur CV Berkah Mandiri, Desa Karang Cengis, Kecamatan Bukateja, Purbalingga, Jawa Tengah.

\section{Materi Penelitian}

Bahan utama penelitian adalah tepung kunyit (Curcuma longa), tepung sambiloto (Andrographis paniculata), ransum penelitian disusun isonutrien dan 150 ekor ayam petelur strain Isa Brown umur 17 minggu. Tepung sambiloto dan tepung kunyit dibuat dari rimpang kunyit dan sambiloto yang dibeli dari pasar lokal.

\section{Pelaksanaan Penelitian}

Penelitian diawali dengan pembuatan tepung kunyit dan tepung sambiloto. Kunyit diiris melintang dengan tebal $2 \mathrm{~mm}$, kemudian dikeringkan dengan sinar matahari hingga kering (kadar air 14\%). Bahan kemudian digiling, dilanjutkan dengan pengayakan menggunakan saringan ukuran 25 mesh. Tepung sambilototo dibuat dari tanaman sambiloto, dipotong-potong berukuran panjang $2 \mathrm{~cm}$, selanjutnya dikeringkan dengan sinar matahari sampai kering (kadar air 14\%). Bahan selanjutnya digiling, dan dilakukan pengayakan menggunakan ayakan berukuran 25 mesh. Ransum perlakuan disusun dari beberapa bahan pakan yaitu jagung, bekatul dan konsentrat ayam petelur disusun iso energi dan protein dengan kandungan energi 2720 $\mathrm{kcal} / \mathrm{kg}$ dan protein 17,2 . Ransum dibedakan berdasarkan perbedaan level suplementasi campuran tepung kunyit (TK) dan tepung sambiloto (TS) yaitu P0 ( $0 \% \mathrm{TK}+0 \% \mathrm{TS})$; P1 $(5 \mathrm{~g} / \mathrm{kg}$ TK $+5 \mathrm{~g} / \mathrm{kg}$ TS $) ;$ P2 $(10 \mathrm{~g} / \mathrm{kg}$ TK $+10 \mathrm{~g} /$ $\mathrm{kg}$ TS ) ; P3 (15 g/kg TK $+15 \mathrm{~g} / \mathrm{kg}$ TS ) dan P4 $(20 \mathrm{~g} / \mathrm{kg} \mathrm{TK}+20 \mathrm{~g} / \mathrm{kg}$ TS $)$. Ransum perlakuan diberikan pada ayam, mulai umur 17 minggu sampai umur 30 minggu. Ransum diberikan secara adlibitum. Kandungan nutrien dan komposisi ransum perlakuan dicantumkan pada Tabel 1.

\section{Peubah yang Diamati}

Variabel penelitian dilakukan pada saat ayam berumur 18 sampai 30 minggu, meliputi konsumsi pakan, umur dewasa kelamin (HDA $5 \%$ ), produksi telur (HDA), konversi pakan, berat telur, berat yolk, dan berat kerabang.

\section{Konsumsi Pakan}

Konsumsi pakan mingguan diukur setiap minggu sekali dengan cara mengurangi jumlah pakan yang disediakan pada awal minggu (g/ekor/minggu) dengan sisa pakan pada akhir minggu (g/ekor/minggu). Ratarata konsumsi pakan (g/ekor/hari) dihitung berdasarkan konsumsi pakan kumulatif mingguan dibagi dengan lama hari penelitian.

\section{Umur Dewasa Kelamin}

Umur dewasa kelamin diukur berdasarkan hari tercapainya produksi telur (HDA) minimal 5\% pada setiap ulangan.

\section{Hen Day Average (HDA)}

HDA diukur pada setiap ulangan berdasarkan jumlah produksi telur harian dibagi dengan jumlah ayam dikalikan $100 \%$.

\section{Berat Telur}

Berat telur (g/butir) diukur dengan cara menimbang keseluruhan telur yang dihasilkan pada setiap selama 12 minggu dibagi dengan jumlah telur (butir) yang dihasilkan.

\section{Berat Yolk}

Berat kuning telur (Yolk) dihitung dengan cara menimbang sampel yolk yang 
Tabel 1. Susunan dan kandungan nutrien ransum perlakuan

\begin{tabular}{lrrrrr}
\hline \multirow{2}{*}{ Bahan pakan (kg) } & \multicolumn{5}{c}{ Perlakuan (\%) } \\
\cline { 2 - 6 } & P0 & P1 & P2 & P3 & P4 \\
\hline Jagung & 46,00 & 46,00 & 46,00 & 46,00 & 46,00 \\
Bekatul & 22,00 & 22,00 & 22,00 & 22,00 & 22,00 \\
Bungkil Kedelai & 23,00 & 23,00 & 23,00 & 23,00 & 23,00 \\
Tepung ikan & 6,00 & 6,00 & 6,00 & 6,00 & 6,00 \\
Tepung Tulang & 2,00 & 2,00 & 2,00 & 2,00 & 2,00 \\
Tepung Kapur & 1,00 & 1,00 & 1,00 & 1,00 & 1,00 \\
\hline Jumlah & 100 & 100 & 100 & 100 & 100 \\
\hline Tepung sambiloto (g/kg)+ & $0+0$ & $5+5$ & $10+10$ & $15+15$ & $20+20$ \\
tepung kunyit (g/kg) ransum & 17,2 & 17,2 & 17,2 & 17,2 & 17,2 \\
\hline Protein kasar (\%) & 2720 & 2720 & 2720 & 2720 & 2720 \\
Energi termetabolis (kcal/g) & 4,98 & 4,98 & 4,98 & 4,98 & 4,98 \\
Serat kasar (\%) & 3,98 & 3,98 & 3,98 & 3,98 & 3,98 \\
Lemak kasar (\%) & 2,72 & 2,72 & 2,72 & 2,72 & 2,72 \\
Ca (\%) & 0,86 & 0,86 & 0,86 & 0,86 & 0,86 \\
P (\%) & & & &
\end{tabular}

diperoleh pada akhir minggu ke 26 dan 30 dari setiap ulangan. Yolk diperoleh dengan memecah telur, kemudian dipisahkan menggunakan egg separator, dan ditimbang.

\section{Konversi Pakan}

Konversi pakan dihitung dengan cara membagi keseluruhan konsumsi pakan dengan berat telur pada waktu dan satuan yang sama, dihitung dari masing-masing ulangan.

\section{Rancangan Percobaan}

Penelitian ini menggunakan rancangan acak lengkap pola searah dengan menggunakan 5 perlakuan dan setiap perlakuan menggunakan tiga kali ulangan. P0 adalah ransum kontrol ( $0 \%)$, P1 adalah suplementasi campuran TKS $10 \mathrm{~g} / \mathrm{kg} ; \mathrm{P} 2$ campuran TKS $20 \mathrm{~g} / \mathrm{kg}$; P3 campuran TKS $30 \mathrm{~g} / \mathrm{kg}$ dan P4 campuran TKS $40 \mathrm{~g} / \mathrm{kg}$. Data yang diperoleh dianalisis dengan analisis variansi, dilanjutkan dengan uji DMRT menggunakan SPSS.

\section{HASIL DAN PEMBAHASAN}

Variabel hasil penelitian yang meliputi konsumsi pakan, umur dewasa kelamin,
HDA, konversi pakan, berat telur, berat yolk dan berat kerabang tertera pada Tabel 2 .

\section{Konsumsi Pakan}

Analisis variansi menunjukkan peningkatan level suplementasi TKS dalam ransum, secara nyata $(\mathrm{P}<0,05)$ semakin menurunkan konsumsi pakan. Konsumsi pakan pada perlakuan P4 (104,7 g/ekor/hari) dan P3 (104,7 g/ekor/hari) secara nyata lebih rendah dari pada P0 (109,1 g/ekor/hari), P1 (107,7 g/ekor/hari) dan P2 (107,1 g/ekor/ hari). Penurunan konsumsi pakan, secara nyata terjadi pada minggu-minggu awal perlakuan. Hal ini menunjukan suplementasi campuran kunyit dan sambiloto menurunkan nafsu makan akibat berubahnya rasa dan warna pakan. Hal ini mengindikasikan bahwa suplementasi tepung kunyit dan kayu manis mengakibatkan adanya perubahan aroma pakan dan palatabilitas pakan. Hal yang sama ditunjukkan oleh beberapa hasil penelitian. Rahardja et al. (2016) menyatakan semakin tinggi suplementasi tepung kunyit mulai dari $0,1,2$ dan 4\% dalam ransum ayam petelur Hisex Brown sejak umur 80 sampai 92 minggu akan semakin menurunkan konsumsi pakan. Malekizadeh et al. (2012) 
Tabel 2. Kinerja ayam petelur Isa Brown pada berbagai aras suplementasi campuran tepung kunyit dan sambiloto

\begin{tabular}{|c|c|c|c|c|c|}
\hline \multirow{2}{*}{ Kinerja } & \multicolumn{5}{|c|}{ Perlakuan } \\
\hline & P0 & P1 & P2 & P3 & P4 \\
\hline $\begin{array}{l}\text { Konsumsi pakan (g/ } \\
\text { ekor/hari) }\end{array}$ & $109,1 \pm 0,85^{\mathrm{a}}$ & $107,7 \pm 1,00^{\mathrm{ab}}$ & $107,1 \pm 0,57^{\mathrm{b}}$ & $104,7 \pm 0,42^{c}$ & $104,7 \pm 1,28^{c}$ \\
\hline $\begin{array}{l}\text { Umur dewasa } \\
\text { kelamin (hari) }\end{array}$ & $128,7 \pm 0,58^{\mathrm{a}}$ & $129,0 \pm 2,00^{\mathrm{a}}$ & $130,3 \pm 1,52^{\mathrm{a}}$ & $136,7 \pm 1,15^{\mathrm{b}}$ & $139,3 \pm 1,53^{\mathrm{c}}$ \\
\hline HDA (\%) & $77,8 \pm 0,45^{\mathrm{a}}$ & $79,76 \pm 0,42^{\mathrm{b}}$ & $78,2 \pm 0,25^{\mathrm{a}}$ & $76,9 \pm 0,41^{\mathrm{c}}$ & $76,7 \pm 0,40^{\mathrm{c}}$ \\
\hline Konversi pakan & $2,41 \pm 0,01^{\mathrm{a}}$ & $2,32 \pm 0,03^{b}$ & $2,39 \pm 0,21^{\mathrm{ac}}$ & $2,36 \pm 0,21^{\mathrm{c}}$ & $2,39 \pm 0,02^{\mathrm{ac}}$ \\
\hline Berat telur (g/butir) & $58,1 \pm 0,25^{\mathrm{a}}$ & $58,6 \pm 0,53^{\mathrm{ab}}$ & $57,2 \pm 0,40^{c}$ & $57,6 \pm 0,53^{\mathrm{bc}}$ & $57,0 \pm 0,21^{\mathrm{c}}$ \\
\hline Berat Yolk (g/butir) & $15,4 \pm 0,16^{\mathrm{a}}$ & $15,6 \pm 0,26^{\mathrm{a}}$ & $15,1 \pm 0,11 b$ & $14,9 \pm 0,28^{\mathrm{b}}$ & $14,5 \pm 0,10^{\mathrm{c}}$ \\
\hline $\begin{array}{l}\text { Berat kerabang (g/ } \\
\text { butir) }\end{array}$ & $7,1 \pm 0,14^{\mathrm{a}}$ & $7,2 \pm 0,16^{\mathrm{a}}$ & $7,1 \pm 0,16^{\mathrm{a}}$ & $7,2 \pm 0,18^{\mathrm{a}}$ & $7,3 \pm 0,13^{\mathrm{a}}$ \\
\hline
\end{tabular}

Keterangan: ${ }^{\mathrm{a}, \mathrm{b}}$ pada kolom yang sama menunjukkan hasil yang berbeda nyata $(\mathrm{P}<0,05)$

menyatakan hal yang sama bahwa ransum ayam petelur pada umur 103 sampai 112 minggu yang disuplementasi dengan tepung kunyit 1 sampai 3\% menghasilkan konsumsi pakan yang lebih rendah dibanding ransum kontrol. Riasi (2012) peningkatan aras kunyit sebesar 0,15 dan $0,20 \%$ dalam ransum akan menurunkan konsumsi pakan.

\section{Umur Dewasa Kelamin}

Suplementasi TKS dalam ransum akan mempengaruhi capaian UDK. Suplementasi TKS akan sedikit menunda UDK. Hal yang sama dinyatakan oleh Saraswati et al. (2013) bahwa suplementasi tepung kunyit pada puyuh akan menunda umur bertelur pertama. Penundaan dewasa kelamin tersebut diduga karena penggunaan herbal, mempengaruhi aktivitas hormon reproduksi. Thakur et al. (2009) menyatakan kunyit menurunkan aktivitas gonadotrophin FSH dan LH. Penggunaan kunyit juga menyebabkan degenerasi folikel graff dan epithel germinal ovarium sehingga menyebabkan infertilitas pada tikus betina (Mohebbati et al. 2017)

\section{Hen Day Average}

Suplementasi TKS pada P1 (aras $10 \mathrm{~g} / \mathrm{kg}$ ) akan memperbaiki HDA, namun peningkatan suplementasi TKS pada aras yang lebih tinggi yaitu P2, P3 dan P4 akan menurunkan HDA. Hal ini menunjukkan bahwa campuran TK dan TS sampai aras $10 \mathrm{~g} /$ kg mampu memperbaiki efisiensi penggunaan pakan. Kunyit dapat memperbaiki kecernaan ransum, karena merangsang sekresi enzimenzim pencernaan. Dinyatakan oleh Platel and Srinivasan (2000) curcumin mampu merangsang sekresi enzim pencernaan dan lipase dari pankreas. Ransum yang suplementasi curcumin pada level $0,2 \mathrm{~g} / \mathrm{kg}$ dapat memperbaiki ukuran dan berat usus kecil, sehingga dapat memperbaiki penyerapan nutrien (Rajput et al., 2013). Campuran fitobiotik dapat meningkatkan imunitas dan memperbaiki absorbsi nutrien sehingga memperbaiki pertumbuhan (Hashemi and Davoodi, 2010). Penggunaan tepung kunyit dan sambiloto, yang disuplementasikan dalam ransum dapat meningkatkan kecernaan, memperbaiki absorbsi nutrien dan menekan perkembangan mikrobia yang merugikan (Platel and Srinivasan, 2000). Sambiloto mempunyai aktivitas dalam menjaga mikroflora saluran cerna yang menguntungkan diantaranya Lactobacilli, serta menghambat bakteri yang bersifat merugikan yaitu E. Coli dan Staphylococci (Guthter and Ulfah, 2003). Akivitas senyawa dalam bahan herbal dapat memperbaiki kecernaan dan metabolisme protein, glukosa, dan memperbaiki sintesis energi (Ulfah, 2006). Penggunaan pada aras yang lebih tinggi, diatas $10 \mathrm{~g} / \mathrm{kg}$ akan menurunkan HDA, hal ini terkait dengan menurunnya konsumsi pakan. Hal senada 
juga dilaporkan Yulianti et al. (2015), bahwa suplementasi tepung sambiloto pada aras 0,4\% akan menurunkan produksi telur.

Peningkatan suplementasi TKS menghasilkan konversi pakan antar perlakuan berbeda nyata. Konversi pakan pada T2 secara nyata paling baik, dibandingkan dengan perlakuan lainnya. Hal ini menunjukkan bahwa kombinasi TKS pada aras 10g/ $\mathrm{kg}$ menghasilkan penggunaan pakan yang paling efisien. Hal ini membuktikan bahwa suplementasi TKS dalam ransum akan meningkatan efisiensi penggunaan pakan untuk produksi telur. Curcumin dalam kunyit berperan memperbaiki nafsu makan, kecernaan, menjaga mikroflora yang mengguntungkan dan meningkatkan absorbsi nutrien dari saluran cerna. Sedang sambiloto mempunyai peranan sebagai anti bakteri.

\section{Berat Telur, Berat Yolk, dan Berat Kerabang Telur}

Peningkatan suplementasi TKS dalam ransum akan menurunkan berat telur, berat yolk maupun berat kuning telur. Penurunan berat telur terkait dengan konsumsi pakannya. Ransum yang disuplementasi TKS akan menurunkan konsumsi pakan sebagai akibat berubahnya palatabilitas. Peningkatan suplementasi TKS pada aras R3 mulai menurunkan berat yolk. Hal ini sejalan dengan menurunnya berat telur.

Peningkatan suplementasi TKS menghasilkan berat kerabang telur berbeda tidak nyata. Hal ini menunjukkan suplementasi TKS tidak mempengaruhi absorbsi maupun deposisi mineral terutama $\mathrm{Ca}$ untuk pembentukan telur. Hasil yang sama dinyatakan Malekizadeh et al. (2012) bahwa tepung tepung kunyit yang disuplementasikan sampai aras $10,0 \mathrm{~g} / \mathrm{kg}$ dan $30,0 \mathrm{~g} / \mathrm{kg}$ tidak mempengaruhi berat kerabang telur. Hal tersebut disebabkan tepung kunyit tidak mempengaruhi lingkungan internal uterus dalam sintesis kerabang (Radwan et al., 2008)

\section{KESIMPULAN}

Suplementasi campuran tepung kunyit dan sambiloto sampai aras $40 \mathrm{~g} / \mathrm{kg}$ dalam ransum tidak dapat memperbaiki kinerja ayam petelur, namun suplementasi pada aras $10 \mathrm{~g} /$ $\mathrm{kg}$ dalam ransum akan memperbaiki produksi telur (HDA) dan konversi pakan ayam petelur, sedang variabel produksi lainnya relatif sama.

\section{DAFTAR PUSTAKA}

Riasi, A. 2012. Production performance, egg quality and some serum metabolites of older commercial laying hens fed different levels of turmeric rhizome (Curcuma longa) powder. Journal of Medicinal Plants Research, 6(11).

Abdullah, S., Amalina, S., Abidin, Z., Murad, N. A. and Makpol, S. 2010. Ginger extract (Zingiber officinale) triggers apoptosis and G0/G1 cells arrest in HCT 116 and HT 29 colon cancer cell lines. African Journal of Biochemistry Research, 4(5): 134-142.

Ammon, H. P. T., Safayhi, H., Mack, T. and Sabieraj, J. 1993. Mechanism of antiinflammatory actions of curcumine and boswellic acids. Journal of Ethnopharmacology, 38(23): $105-112$.

Arafa, H. M. M. 2005. Curcumin attenuates diet-induced hypercholesterolemia in rats. Medical Science Monitor, 11(7): 228-234.

DJPKH. 2019. Statistik Peternakan dan Kesehatan Hewan 2019/ Livestock and Animal Health Statistics 2019. http://ditjenpkh.pertanian.go.id.

Gumus, H., Oguz, M. N., Bugdayci, K. E., and Oguz, F. K. 2018. Effects of sumac and turmeric as feed additives on performance, egg quality traits, and blood parameters of laying hens. Revista Brasileira de Zootecnia, 47.

Guther, K.D. and M. Ulfah, 2003. Influence 
of natural essential oils on digestion, metabolism and efficient production. Paper presented at the 4th Buffalo Symposium. New Delhi. India.

Hashemi ,S.R., and H. Davoodi, 2010. Phytogenic as New Class of Feed Additive in Poultry Industry. J.Anim. Vet. Adv 9: 2295-2304

Houshmand, M., Azhar, K., Zulkifli, I., Bejo, M. H., and Kamyab, A. 2012. Effects of non-antibiotic feed additives on performance, immunity and intestinal morphology of broilers fed different levels of protein. South African Journal of Animal Sciences, 42(1): 22-32.

Joseph, J. and Solomon, J. 2014. Andrographis paniculata: A Review of its Traditional Uses, Phytochemistry and Pharmacology. Med Aromat Plants 3: 169.

Jouybari, M. G., Pour, V. R., Mohammad, M., and Nagharchi, Z. 2009. The effect of novel probiotic on blood parameters and performance in broiler chickens. Journal of Cell and Animal Biology, 3(8): 141-144.

Kiuch, F., Goto, Y., Sugimoto, N., Tsuda, Y., Akao, N., and Kondo, K. 1993. Nematocidal Activity of Turmeric: Synergistic Action of Curcuminoids. Chemical and Pharmaceutical Bulletin, 41(9): 1640-1643.

Malekizadeh, M., Moeini, M. M., and Ghazi, S. 2012. The effects of different levels of ginger (Zingiber officinale Rosc) and Turmeric (Curcuma longa Linn) rhizomes powder on some blood metabolites and production performance characteristics of laying hens. Journal of Agricultural Science and Technology, 14(1): 127-134.

Mohebbati, R., Anaeigoudari, A. and Khazdair, M. R. 2017. The effects of Curcuma longa and curcumin on reproductive systems. Endocrine Regulations, 51(4): 220-228.
Osawa, T., Sugiyama, Y., Inayoshi, M. and Kawakishi, S. 1995. Antioxidative Activity of Tetrahydrocurcuminoids. Bioscience, Biotechnology, and Biochemistry, 59(9): 1609-1612.

Platel, K. and Srinivasan, K. 2000. Influence of dietary spices and their active principles on pancreatic digestive enzymes in albino rats. Nahrung Food, 44(1): 42-46.

Radwan, N. L., Hassan, R. A., Qota, E. M., and Fayek, H. M 2008. Effect of natural antioxidant on oxidative stability of eggs and productive and reproductive performance of laying hens. Int. J. Poult. Sci., 7: 134-150.

Rahardja, D., Hakim, M., and Sri Lestari, V. 2016. Egg Production Performance of Old Laying Hen Fed Dietary Turmeric Powder. 9(7): 748-752.

Rajput, N., Muhammad, N., Yan, R., Zhong, X., and Wang, T. 2013. Effect of dietary supplementation of curcumin on growth performance, intestinal morphology and nutrients utilization of broiler chicks. Journal of Poultry Science, 50(1): 44-52.

Saraswati, T. R., Manalu, W., Ekastuti, D. R., and Kusumorini, N. 2013. The role of turmeric powder in lipid metabolism and its effect on quality of the first quail's egg. Journal of the Indonesian Tropical Animal Agriculture, 38(2): 123-130.

Saraswati, Tyas Rini, Manalu, W., Ekastuti, D. R., and Kusumorini, N. 2014. Effect of turmeric powder to estriol and progesterone hormone profile of laying hens during one cycle of ovulation. International Journal of Poultry Science, 13(9): 504-509.

Saraswati, Tyas Rini, and Tana, S. 2016. Physiological Condition of First Female and Male Offspring of Japanese Quail (Coturnix japonica) whose Parents were Supplemented by Turmeric Powder. 6(2): 59-65. 
Thakur, S., Bawara, B., Dubey, A., Nandini, D., Chauhan, N. S. and Saraf, D. K. 2009. Effect of Carum carvi and Curcuma longa on hormonal and reproductive parameter of female rats. Int J Phytomed 1: 31-38.

Tipakorn, N. 2002. Effect of Andrographis paniculata (Burm F.) Nees On Performance, Mortality and Coccidiosis In Broiler Chickens.
Doctoral Dissertation. Georg-AugustUniversity, Gottingen, Germany.

Yulianti, D. L, Pratiwi Trisunuwati, O. Sjofjan and E. Widodo. 2015. Effect of Andrographis paniculata a Phytobiotic on Consumption, Feed Conversion and Mojosari Duck Egg Production. International Journal of Poultry Science 14 (9): 529-532. 